\title{
ОПЫТ ПРИМЕНЕНИЯ СЕДИМЕНТОМЕТРИЧЕСКОГО АНАЛИЗА ДЛЯ ВЫЯСНЕНИЯ УСЛОВИИ СЛАНЦЕНАКОПЛЕНИЯ
}

\author{
Н. Л. ДиЛАКТОРСКиИ, \\ доктор геолого-минералогических наук \\ С. С. БАУКОВ, \\ кандидат геолого-минералогических наук
}

\section{М. М. ДИЛАКТОРСКАЯ}

\section{I. ВВЕДЕНИЕ}

В 1956 г. при изучении состава и свойств неорганической составляющей кукерсита один из авторов настоящей статьи * высказал мысль о том, что в пределах Прибалтийского сланцевого бассейна имеются исключительно благоприятные условия залегания пород для проведения исследований по изучению условий осадконакопления в пределах узкого отрезка геологического времени. Автор предложил также метод выполнения этих работ, заключающийся в установлении гранулометрического состава устойчивых против выветривания и растворения терригенных минералов, выделенных из различных слоев сланценосной толщи. Из двух пригодных для этой цели минералов - кварца и ортоклаза - был рекомендован первый, так как ортоклаз в сланцевых и известняковых слоях месторождения встречается не только в виде терригенных, но и в виде аутигенных образований. Следует отметить, что до настоящего времени такие работы по сланцам не проводились.

Работы некоторых исследователей содержат целый ряд интересных, иногда противоречащих друг другу соображений о причинах и условиях, определявших смену продуктивных, содержащих кероген, и известняковых, бедных керогеном слоев. Так, А. Шамарин $\left[{ }^{8}\right]$, М. Витлих и С. Вешняков [ๆ] и А. Эпик [9, $\left.{ }^{10}\right]$ выделяли в горючих сланцах и известняках, слагающих промышленную пачку, две составные части аутохтонную (или таласогенную), к которой' они относили органическое вещество и карбонаты кальция и магння, и терригенную (или кластическую), состоящую из глинистого материала и кварцевых зерен. А. Эпиком было отмечено, что хотя в сланцах кластического материала больше, чем в известняках, по этому признаку еще нельзя устанавливать положение береговой линии и определять, какие слои, сланцевые или известняковые, отлагались дальше (или ближе) от береговой линии и области эрозии, так как, во-первых, содержание этого материала не находится в закономерном соотношении с количеством органического вещества и, во-вторых, из-за тонкости и малого количества кластического вещества не были установлены различия по крупности его зерен. Колебания в содержании обломочного материала А. Эпик объясняет изменением скорости накопления других составных компонентов - органического вещества и карбонатов.

* Н. Л. Д ил ак то р ск и й, Изучение состава и свойств неорганической составляющей кукерсита, Отчет сектора физико-химических исследований ИССМ АН ЭССР за 1957 r. 
Не решен этот вопрос и по данным изучения остатков фауны. А. Эпик считает, что относительная бедность сланцевых слоев фауной (отсутствуют ползающие и прикрепленные формы - брюхоногие, моллюски, цистоидеи, за исключением замковых брахиопод и мшанок) по сравнению с фауной в переслаивающихся с ними известняковых слоях также не может служить достоверным доказательством того, что слои горючего сланца и известняков отлагались на различных глубинах, поскольку указанное фаунистическое различие зависит не столько. от глубины моря, сколько от характера придонных отложений: сапропель для некоторых бентонных форм был неблагоприятной субстанцией. Х. Линденбайн [7] объясняет переслаивание слоев «сланец-известняк» осцилляцией береговой линии и считает сланцевые слои менее глубоководными, чем известняковые. А. Эпик [9] возражает против такого предположения и ссылается на нахождение в известняках (слои $\mathrm{C}-\mathrm{D}$ ) мелководной известняковой водоросли Siphonea (Coelosphaeridium kohtlense Bekker). Исходя из фаунистической охарактеризованности, он считает, что сланцевая толща кукрузеского горизонта восточной части сланцевого бассейна образовалась при большем удалении от берега, чем синхронная с ней обедненная керогеном известняковая толща западной части бассейна, причем, по его мнению, как сланцевые, так и известняковые слои отлагались в спокойных, однообразных условиях открытого моря, в удалении от берега, на достаточно большой глубине, при которой волнение не доходило до дна, о чем можно судить по условиям захоронения и сохранности окаменелостей (сохранность нежных форм, отсутствие ориентировки), и при которой до дна проникало мало света', о чем свидетельствуют находки безглазых трилобитов (Ampyx rostratus Sars) и трилобитов с высокосидящими глазами (Asaphus robergi Wiman, Lichas inexpectatus, Cybele).

По этому вопросу высказал свое мнение и А. Луха [], который пишет: «Чем объяснить частые и резкие переходы фаций - смену известняка кукерситом и наоборот, это проблема, которую пока трудно разрешить. Кажется невозможным, чтобы это было следствием изменений глубины моря. Скорее мы нмеем здесь дело с последствиями изменений климатических условий в связи с изменениями в режиме. морских течений».

Таким образом, описанные выше различия горючих сланцев и известняков по их компонентному составу и по найденной в них фауне оказываются недостаточными для выяснения различий в условиях осадконакопления. Для этой цели требуется применение новых, более совершенных методов, например определение гранулометрического состава терригенных минералов (кварца) в сланцевых и известняковых прослоях. При решении вопроса о возможности использования результатов гранулометрического анализа зерен терригенного кварца для установления условий седиментащии пород сланцевого бассейна мы исходили из следующих соображений:

а) снос терригенного материала с суши и отложение его в морском бассейне во время накопіления сланцевых или известняковых слоев происходили вне зависимости от скорости накопления органической или карбонатной составляющих;

б) гранулометрический состав зерен терригенных минералов, в том числе и кварца, определялся для каждого из участков морского дна условиями транспортирования зерен и в первую очередь расстоянием от береговой линии;

в) изменение гранулометрического состава зерен терригенного кварца в сторону преобладания мелких частиц в расположенных друг над другом слоях пород сланцевого бассейна свидетельствует об увеличении глубины мөря, и, наоборот, стадии обмеления моря соответствует укрупнение размеров зерен, отлагающихся на дне бассейна;

г) судя по сходному минералогическому составу терригенной (алеврито-глинистой) составляющей в богатых и обедненных керогеном прослоях, нет особых оснований считать, что во время их накопления имели место сколько-нибудь большие изменения интенсивности денудирующих процессов и перемены области сноса;

д) нам представлялась маловероятной возможность объяснения резкой смены сланцевых и известняковых прослоев периодическим чередованием температурного режима моря или периодическим возникновением морских течений, выносивших с 
больших участков морского дна илистые образоважия, содержавшие органические остатки;

е) карбонатная составляющая горючих сланцев и известняков изучаемого разреза является по своему происхождению в основном органогенной.

\section{II. КРАТКАЯ ХАРАКТЕРИСТИКА ИСХОДНОГО МАТЕРИАЛА}

Одиннадцать штуфовых проб весом около 2 кг каждая были отобраны по вертикальному разрезу промышленной пачки сланца на шахте № 10 треста «Эстонсланец». Отобранный материал представлял слои сланца от А до $\mathrm{F}$ включительно и известняковые слои $\mathrm{A}-\mathrm{B}, \mathrm{B}-\mathrm{C}$ и $\mathrm{C}-\mathrm{D}$. Разрез промышленного пласта с указанием мест взятия проб представлен на фиг. 1.

Для получения предварительных данных о содержании во взятых пробах керогена, карбонатов и алеврито-глинистой ссставляющей для всех образцов были определены потери при прокаливании, содержание $\mathrm{CO}_{2}$ и гигроскопической влаги. Результаты пересчета их на составляющие породу компоненты приведены в табл. 1.

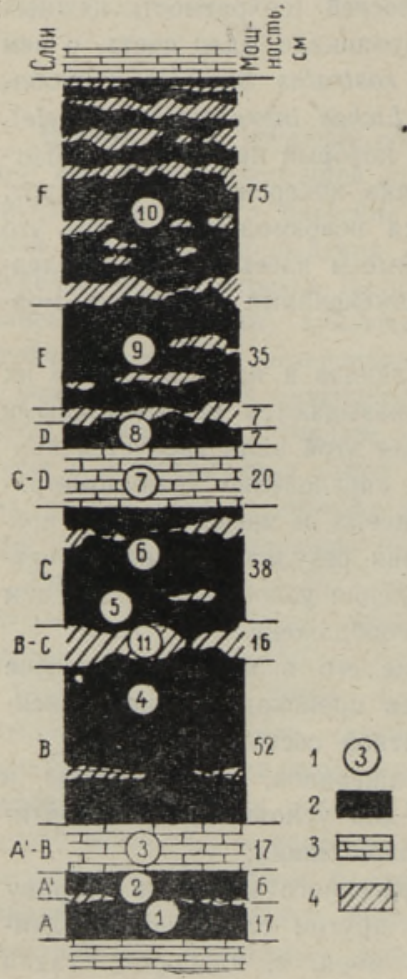

Таблица 1

\begin{tabular}{|c|c|c|c|c|}
\hline \multirow[t]{2}{*}{ Слой } & $\begin{array}{c}\text { Гигроско- } \\
\text { пическая } \\
\text { влага }\end{array}$ & Кероген & $\begin{array}{c}\text { Карбо- } \\
\text { наты }\end{array}$ & $\begin{array}{c}\text { Алеври- } \\
\text { то-глини- } \\
\text { стая } \\
\text { часть }\end{array}$ \\
\hline & \multicolumn{4}{|c|}{$\%$} \\
\hline A & 0,77 & 48,91 & 23,89 & 26,43 \\
\hline $\mathrm{A}^{\prime}$ & 0,77 & 27,42 & 23,04 & 48,77 \\
\hline$A^{\prime}-B$ & - & 8,58 & 63,72 & 27,70 \\
\hline B & 0,4 & 47,76 & 28,35 & 23,49 \\
\hline$B-C$ & 0,52 & 14,40 & 67,24 & 17,84 \\
\hline C (низ) & 0,52 & 47,48 & 18,39 & 33,61 \\
\hline C (верх) & 0,52 & 28,68 & 39,65 & 31,15 \\
\hline$C-D$ & & 3,66 & 76,75 & 19,59 \\
\hline D & 0,56 & 23,24 & 49,67 & 26,53 \\
\hline E & 0,55 & 61,13 & 17,00 & 21,32 \\
\hline $\mathrm{F}$ & 0,47 & 29,06 & 41,05 & 29,42 \\
\hline
\end{tabular}

Фиг. 1. Разрез промышленного пласта горючего сланца эстонского месторождения (шахта № 10): I - место взятия и номер пробы; 2 - горючий сланец; 3 - известняк; 4 - биоморфный известняк, содержащий до $15 \%$ органического вещества.

\section{III. МЕТОД ВЫДЕЛЕНИЯ ЗЕРЕН КРИСТАЛЛИЧЕСКОГО КВАРЦА ИЗ ГОРЮЧИХ СЛАНЦЕВ}

Получение кристаллического кварца из горючего сланца и вмещающих пород состоит из нескольких последовательных операций: подготовки гробы, растворения карбонатов, окисления керогена, растворе- 
ния аморфного кремнезема и растворения ортоклаза, описание которых приводится ниже. *

\section{1. Отбор и подготовка пробы}

Отобранные в шахте пробы сланца и известняков разбиваются на кусочки размером не более 3 см. Из измельченного материала методом квартования отбираются пробы весом 400-500 г, которые помещают в широкогорлые колбы, заливают серным эфиром и оставляют стоять около часа до возможно более полного разрушения кусочков породы. Эфир сливают, пробу высыпают на большой лист плотной бумаги (под тягой) и раздавливают кусочки уже рыхлой породы пальцами. Более прочные известняковые кусочки, не разрушившиеся после эфирной обработки, разбивают легкими ударами пестика в ступке, не растирая их. Размельченный таким способом материал пропускают через сито с диаметром отверстий 2 мм. Не прошедшую через сито часть снова осторожно разбивают в ступке и просеивают до полного прохождения всей пробы через указанное сито. После этого пробы тџцательно перемешивают и сокращают до 200 г. На этом подготовка пробы для химической обработки считается законченной.

Чтобы определить объем исходного материала для получения требуемого количества кварца $(6-10$ г), из небольшой навески $(5-10$ г) каждой анализируемой пробы делается предварительное определение содержания кварца и только после этого приступают к дальнейшей обработке проб, что экономит время и расход реактивов. Вес проб, в зависимости от содержания кварца, составляет от 40 до 200 г. Если проба содержит мало кварца, но много керогена, то навески для дальнейшей обработки не должны превышать 40 г. В этом случае для получения требуемого количества кварца пробу следует разделить на несколько частей по $30-40$ г и обрабатывать их отдельно. Навески известняковых пород могут быть до 200 г.

\section{2. Растворение карбонатов и фильтрование осадка}

Навеску помещают в термостойкий стакан емкостью 1-1,5 л, смачивают водой и обрабатывают 25\%-ным расгвором $\mathrm{HCl}$. Приливать кислоту следует небольшими порциями (по 5 мл), каждый раз по прекращении выделения пузырьков газа $\left(\mathrm{CO}_{2}\right)$ из пробы. После прекращения реакции содержимое стакана следует подогреть и добавить к нему еще немного соляной кислоты. Если при этом $\mathrm{CO}_{2}$ не выделяется, разложение карбонатов можно считать законченным (проверить под микроскопом отсутствие карбонатов).

После обработки соляной кислотой содержимое стакана в горячем виде фильтруют на воронке Бюхнера через двойной бумажный фильтр, промывают водой до нейтральной реакции промывных вод и вместе с фильтром переносят с воронки в тот же стакан, где проба обрабатывалась $\mathrm{HCl}$. Остатки смеси снимают с воронки кусочками фильтра и присоединяют к основному осадку в стакане.

* Методика выделения кварца из горючего сланца была разработана в основном инженером-химиком X. Раудоя. В процессе дальнейшей работы в нее были внесены некоторые изменения и дополнения.

4 TA Toimetised T-2 61 


\section{3. Окисление керогена}

Кероген удаляется методом окисления азотной кислотой. Декарбонированный остаток в стакане слегка смачивают водой и добавляют 200 мл концентрированной серной кислоты (приблизительно 1,5 мл на 1 г пробы); разогревшуюся массу хорошо перемешивают стеклянной палочкой и ставят стакан на электрическую плитку, покрытую листом асбеста. Когда масса в стакане станет слегка дымить, начинают прибавлять по 2-3 мл концентрированной азотной кислоты (можно $60 \%$-ную). При этом начинается энергичное выделение бурых паров $\mathrm{NO}_{2}$. Перемешивать содержимое стакана не следует, так как от этого происходит сильное вспучивание. Новую порцию $\mathrm{HNO}_{3}$ следует прибавлять только после прекращения выделения $\mathrm{NO}_{2}$.

Необходимо тщательно следить за равномерностью нагревания содержимого в стакане, иначе при охлаждении происходит замедление реакции, что ошибочно можно принять за окончание реакции окисления при израсходовании $\mathrm{HNO}_{3}$. Преждевременное добавление новой порции $\mathrm{HNO}_{3}$ может вызвать медленное, но сильное вспучивание содержимого со дна стакана, где температура выше. В этом случае пена может перелиться через край стакана. При перегреве в момент добавления $\mathrm{HNO}_{3}$ может произойти неожиданно бурное выделение $\mathrm{NO}_{2}$, сопровождающееся разбрызгиванием массы. Если при этом пена не спадает и грозит перелиться через край, вспенившуюся поверхность необходимо посыпать порошком соды $\left(\mathrm{Na}_{2} \mathrm{CO}_{3}\right)$, в результате чего пена сразу опадает. Чашку с содой нужно всегда иметь под рукой, но пользоваться содой следует только в крайнем случае, когда бурная реакция может повести к выбрасыванию содержимого стакана и, следовательно, к потере кварца. Полезно иметь под руками и запасной термостойкий стакан для отливания внезапно увеличившейся в объеме массы из рабочего стакана. Стеклянная палочка для перемешивания содержимого в стакане должна быть на 5-6 см выше стакана. Работать нужно объязательно в защитных очках. При соблюдении всех вышеуказанных мер предосторожности и при наличии хорошей вентиляции эта стадия обработки сланца протекает без осложнений, и в течение одного рабочего дня основную часть органики из пробы можно удалить. 3а 15-20 мин. до окончания рабочего дня стакан с обрабатываемой пробой следует снять с плитки и дать ему остыть. Только после этого можно выключать тягу. При аккуратной работе можно одновременно обрабатывать $3-4$ пробы.

На следующий день обработка пробы начинается с медленного разогревания ее до максимально горячего состояния, не давая пене переливаться через край. После разогревания пробу обрабатывают $\mathrm{HNO}_{3}$ по описанному выше способу.

В процессе обработки азотной кислотой содержимое стакана постепенно разжижается и изменяет окраску из черно-коричневой в коричнево-красную. Затем цвет становится красным, и содержимое стакана перестает вспениваться; на дне стакана заметно начинает оседать белый минеральный осадок, количество которого постепенно увеличивается. В дальнейшем содержимое стакана постепенно приобретает желтую окраску, затем все больше светлеет и по окончании реакции в стакане остается белый осадок в слегка желтовато-зеленоватом растворе.

В последнюю стадию окисления керогена содержимому стакана нужно дать как можно больше кипеть и при этом не добавлять $\mathrm{HNO}_{3}$, 
В случае почернения светлого осадка стакан следует охладить и добавить в него несколько миллилитров $\mathrm{HNO}_{3}$ до просветления массы. Если в процессе кипения в течение $1-1,5$ часа после добавления последней порции азотной кислоты осадок больше не темнеет, процесс окисления керогена можно считать законченным.

Содержимое стакана охлаждают и осторожно переливают в литровый стакан, наполненный на $1 / 3$ дистиллированной водой. Разогревшуюся при разбавлении водой смесь фильтруют на воронке Бюхнера через двойной плотный фильтр и промывают дистиллированной водой до нейтральной реакции. Осадок содержит кварц, ортоклаз и аморфный кремнезем, выделившийся при растворении силикатов.

\section{4. Растворение аморфного кремнезема}

Аморфный кремнезем можно растворить либо в $3 \%$-ном растворе едкого натра, либо в 5\%-ном растворе углекислого натрия. Для этого осадок с воронки Бюхнера осторожно снимают стеклянной палочкой и переносят в стакан, в котором производилось окисление керогена, а остатки смывают в тот же стакан из промывалки холодным 5\%-ным раствором соды или $3 \%$-ным раствором едкого натра. Проведенными опытами установлено, что в обоих случаях при этом растворяется и кристаллический кварц. Аморфный кремнезем почти полностью растворяется в 5\%-ном растворе соды при кипячении в течение получаса, но при этом растворяется $1,44 \%$ кристаллического кварца; обработка в $3 \%$-ном растворе $\mathrm{NaOH}$ при температуре $70-80^{\circ}$ в течение $15-20$ минут обеспечивает полное растворение аморфного кремнезема, причем растворяется $1,25 \%$ кристаллического кварца, что соответствует растворению на поверхности зерен слоя толщиной $0,09 \mu$. Таким образом, более рациональным является растворение аморфного кремнезема в щелочи. Метод этот состоит в следующем.

К осадку в стакане приливают $400-500$ мл горячего $3 \%$-ного раствора $\mathrm{NaOH}$ и ведут обработку в течение 15-20 мин. при температуре не выше $80^{\circ} \mathrm{C}$. (Обработку $5 \%$-ным раствором соды ведут в том же порядке, но смесь кипятят в течение получаса.) После этого осадок фильтруют через взвешенный стеклянный фильтр № 4. Осадок на фильтре промывают горячей водой и, если цвет осадка желтый, $25 \%$-ным раствором $\mathrm{HCl}$ до полного осветления. Кислоту смывают дистиллированной водой до исчезновения иона хлора в промывных годах. Осадок, содержащий кварц и ортоклаз, высушивают вместе с фильтром и взвешивают. Под микроскопом в осадке, кроме кварца и ортоклаза, можно обнаружить единичные зерна турмалина, циркона, рутила. Последние в случае необходимости можно удалить обработкой осадка в тяжелой жидкости с удельным весом 2,7.

При обработке осадка 5\%-ным раствором соды в нем иногда может остаться часть нерастворившегося аморфного кремнезема. В таком случае обработку содой нужно провести вторично, применяя для сокращения потерь кварца $3 \%$-ный раствор соды.

\section{5. Растворение ортоклаза во фтороборной кислоте}

Для удаления ортоклаза из полученной после растворения аморфного кремнезема смеси кварц-ортоклаз был использован метод, описанный В. Ф. Гиллебрандом [1]. Этот метод основан на способности фто-

5 TA Toimetised T-2 61 
роборной кислоты $\left(\mathrm{HBF}_{4}\right)$ растворять многие силикаты (волластонит, биотит, ортоклаз, альбит, мусковит, пироксен и др.) и столь слабо растворять кварц, что на потерю его можно ввести поправку. На 24 часа обработки при $50^{\circ} \mathrm{C}$ поправка на потерю кварца равна $0,34 \%$, в то время как при применении кремне-фтористоводородной кислоты она составляет $0,7 \%$ на 24 часа обработки при комнатной температуре.

Фтороборная кислота приготовляется следующим образом. В платиновую чашку емкостью 125 мл вливают 75 мл чистой $48 \%$-ной плавиковой кислоты, охлаждают в ледяной ванне и прибавляют маленькими порциями 32 г. перекристаллизованной борной кислоты. Каждую следующую порцию всыпают только тогда, когда предыдущая растворится. Для растворения последних порций борной кислоты смесь нагревают на водяной бане. Затем раствор концентрируют выпариванием примерно до 50 мл, охлаждают до $0-5^{\circ} \mathrm{C}$ и фильтруют для удаления выпавших кристаллов борной кислоты. Полученная фтороборная кислота должна иметь плотность около 1,45 и не содержать фторидов (не должна давать осадка с раствором $\mathrm{CaCl}_{2}$ ). Хранить фтороборную кислоту следует в восковых или каучуковых сосудах, но фильтровать ее можно и через стеклянную воронку ([$\left.{ }^{1}\right]$, стр. 855).

Растворение ортоклаза во фтороборной кислоте ведут следующим образом. Высушенный и взвешенный осадок после удаления аморфного кремнезема слегка разминают платиновым шпателем в платиновой чашке, добавляют на 1 г порошка 20-25 мл фтороборной кислоты, 5 мл фосфорной кислоты $d=1,39$ и 10 мл $30 \%$-ного раствора $\mathrm{FeCl}_{3}$. Содержимое чашки хорошо перемешивается платиновым шпателем. Чашка устанавливается в термостате с асбестовой обкладкой внутренней части при температуре $50^{\circ} \mathrm{C}$. При этом нужно следить за цветом раствора; если желтая окраска исчезает, необходимо добавить несколько миллилитров $30 \%$-ного раствора $\mathrm{FeCl}_{3}$.

Для установления сроков полного растворения ортоклаза обработка фтороборной кислотой проводилась в течение $48,36,24$ и 18 часов. Только в последнем случае ортоклаз растворялся не полностью. Таким образом, для полного растворения ортоклаза достаточно 24 часов. Проверку на отсутствие ортоклаза следует проводить в иммерсионных препаратах под микроскопом (с жидкостью 1,540).

По окончании обработки осадка фтороборной кислотой его фильтруют через плотный фильтр на стеклянной воронке; промывают сначала смесью $25 \%$-ной соляной и борной кислот $(1-2$ г борной кислоты на 100 мл соляной) для растворения выпадающих фторидов, а затем горячей дистиллированной водой до исчезновения иона хлора. Промытый осадок высушивают в термостате при температуре $109-105^{\circ} \mathrm{C}$, снимают с фильтра и взвешивают. Фильтр можно осторожно озолить (при температуре около $400^{\circ} \mathrm{C}$ ), а остаток его присоединить к основному, предварительно его взвесив.

Необходима окончательная проверка пробы на отсутствие ортоклаза и фторидов под микроскопом.

\section{IV. МЕТОДИКА СЕДИМЕНТАЦИОННЫХ АНАЛИЗОВ}

Предварительный просмотр под микроскопом выделенного из сланцевых и известняковых слоев кварца показал, что основная масса его зерен имеет диаметр менее $25 \mu$. Поэтому при выборе метода гранулометрического анализа, учитывая крайне скудные количества (3-6 г) полученного материала, мы остановились на методе взвешивания зе- 
рен, оседающих при стоянии суспензии на чашечку, подвешенную к коромыслу весов [4]. Этот метод позволяет работать с навесками материала, не превышающими $0,5-1,5$ г, и получать для фракций размером менее $25 \mu$ достаточно точные результаты; при этом можно проводить повторные определения с одним и тем же материалом.

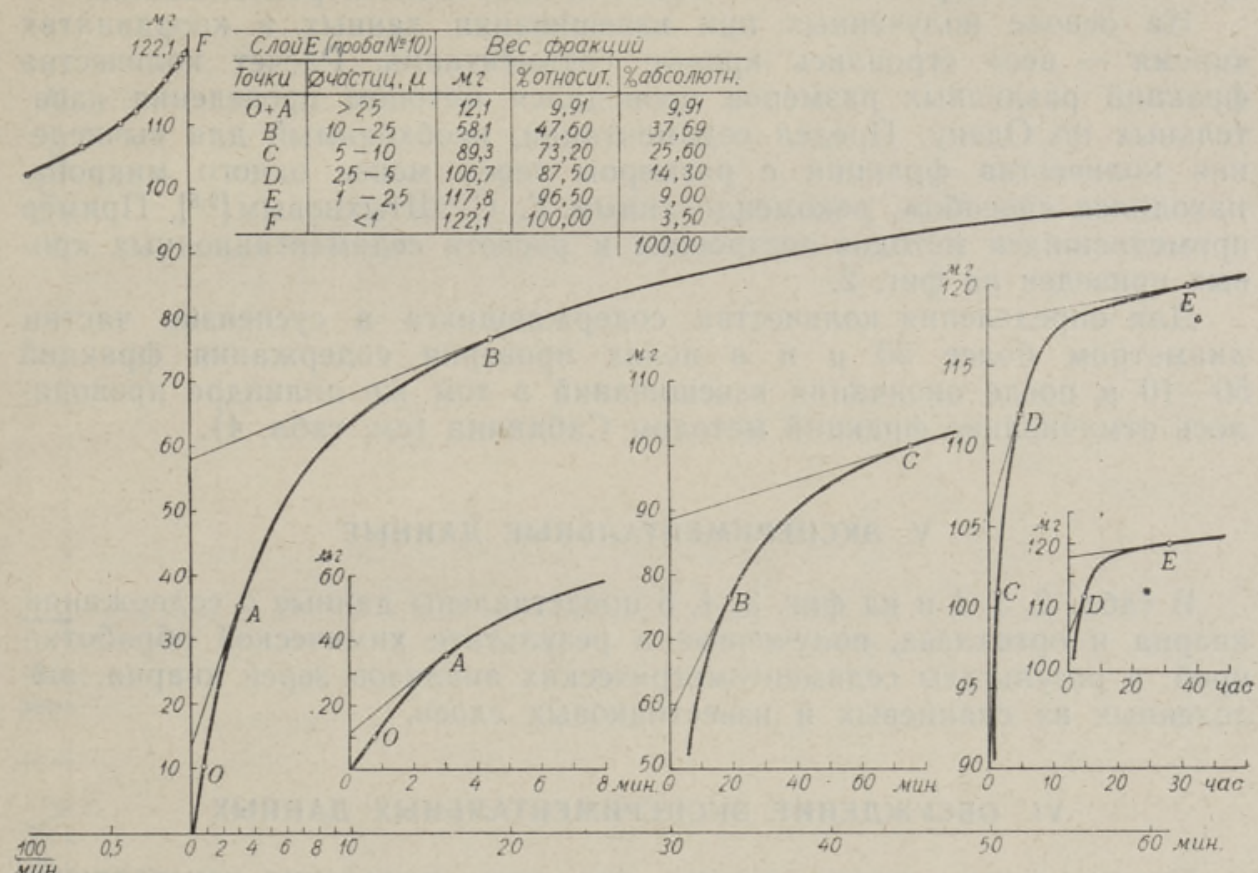

Фиг. 2. Метод построения и графического расчета седиментационной кривой.

Для повышения точности определений веса кварцевых зерен, осаждающихся на чашечку из суспензии, мы пользовались торзионными весами, имеющими, помимо удобства и простоты отсчета показаний, и то преимущество, что при арретировании их во время перерывов между взвешиваниями чашечка для сбора оседающих зерен остается неподвижной. Кварцевая или стеклянная чашечка для сбора осадка была бы слишком тяжелой для имевшихся в нашем распоряжении весов (ВГ-500 мг). Поэтому она была заменена алюминиевой. Вес изготовленной нами из алюминиевой фольги чашечки диаметром 25 мм и глубиной около 2,5 мм вместе с проволочной подвеской не превышал 250 мг. Пробы для седиментационных анализов отвешивались на тех же торзионных весах, на которых проводилась дальнейшая работа. Это дало возможность отказаться от предварительной калибровки весов.

Подготовленные пробы весом в 1 г высыпались в эрленмейеровские колбы с обратным холодильником, содержавшие 150 мл дистиллированной воды, кипятились в них в течение одного часа, после чего переносились в седиментационные цилиндры диаметром около 6 см. Суспензия разбавлялась прокипяченной дистиллированной водой до 225 мл. Для взмучивания суспензии применялась стеклянная палочка с укрепленным на конце ее резиновым диском, диаметр которого был на 5 мм меньше внутреннего диаметра цилиндра. 
Изменения температуры суспензии во время опыта устанавливались измерением температуры воды в стоящем рядом цилиндре. После двухминутного перемешивания включался секундомер и в суспензию на глубину 10 см опускалась чашечка, подвешенная к коромыслу весов (эта операция занимала $5-7$ сек.). Первое взвешивание осадка производилось через 30 сек. с момента окончания перемешивания.

На основе полученных при взвешивании данных в координатах «время - вес» строились кривые седиментации. Расчет количества фракций различных размеров проводился методом проведения касательных по Одену. Предел седиментации, необходимый для вычисления количества фракции с размером зерен менее одного микрона, находился способом, рекомендованным Г. С. Штыхновым [2,5]. Пример применявшихся методов построения и расчета седиментационных кривых приведен на фиг. 2.

Для определения количества содержавшихся в суспензии частиц диаметром более $50 \mu$ и в целях проверки содержания фракций 50 - $10 \mu$ после оконча'єия взвешиваний в том же цилиндре проводилось отмучивание фракций методом Сабанина (см. табл. 4).

\section{V. ЭКСПЕРИМЕНТАЛЬНЫЕ ДАННЫЕ}

В табл. 2, 3, 4 и на фиг. 3, 4, 5 представлены данные о содержании кварца и ортоклаза, полученные в результате химической обработки проб, и результаты седиментометрических анализов зерен кварца, выделенных из сланцевых и известняковых слоев.

\section{VI. ОБСУЖДЕНИЕ ЭКСПЕРИМЕНТАЛЬНЫХ ДАННЫХ}

Прежде всего следует указать, что метод выделения кристаллического кварца из силикатных пород, предложенный В. Гиллебрандом ['], после внесения в него ряда дополнений оказался вполне пригодным для извлечения кварца из горючих сланцев. Этот метод может быть также с успехом применен для извлечения кварца из известняков, доломитов, мергелистых и глинистых пород. Видоизмененный нами метод весового седиментометрического анализа (применение торзионных весов и алюминиевых чашек для взвешивания оседающих фракций) полностью оправдал себя.

Кривые распределения фракций кварца (фиг. 6), построенные на основании данных седиментометрического анализа, имеют для всех слоев сходный характер с четко выраженным максимумом для зерен размером от 10 до $25 \mu$. Это обстоятельство позволяет подтвердить ряд ранее высказанных предположений об условиях седиментации во время образования слоев промпачки сланца: во-первых, о поступлении терригенного материала с одной и той же области сноса; во-вторых, судя по примерно одинаковой степени угловатости зерен кварца, о сохранении условий выветривания горных пород, являвшихся источником терригенного кварца; и, наконец, в-третьих, о сохранении условий транспортирования кластического материала с суши в море.

Относительное содержание в отдельных слоях керогена, карбонатов, алеврито-глинистой составляющей и кварца показано на фиг. 7. Между содержанием алеврито-глинистой части и кварца обнаруживается четко выраженная прямая, но непропорциональная зависимость: количество кварца в слое увеличивается по мере возрастания содержания алеврито-глинистой составляющей и в то же время относитель- 

вых слоев

\begin{tabular}{|c|c|c|c|}
\hline \multirow{3}{*}{ Слой } & \multirow{2}{*}{$\begin{array}{l}\text { Кварц и } \\
\text { ортоклаз }\end{array}$} & \multicolumn{2}{|c|}{ В том числе: } \\
\hline & & кварц & | ортоклаз \\
\hline & \multicolumn{3}{|c|}{$\%$} \\
\hline A & 11,82 & 5,66 & 6,16 \\
\hline $\mathrm{A}^{\prime}$ & 18,57 & 12,01 & 6,56 \\
\hline$A^{\prime}-B$ & 9,60 & 6,26 & 3,34 \\
\hline B & 6,54 & 2,87 & 3,67 \\
\hline$B-C$ & 5,08 & 2,33 & 2,75 \\
\hline С (низ) & 14,26 & 6,34 & 7,92 \\
\hline C (верх) & 11,96 & 5,54 & 6,42 \\
\hline$C-D$ & 4,68 & 2,57 & 2,11 \\
\hline D & 15,00 & 7,95 & 7,05 \\
\hline E & 7,84 & 3,36 & 4,48 \\
\hline F & 10,73 & 5,97 & 4,76 \\
\hline
\end{tabular}

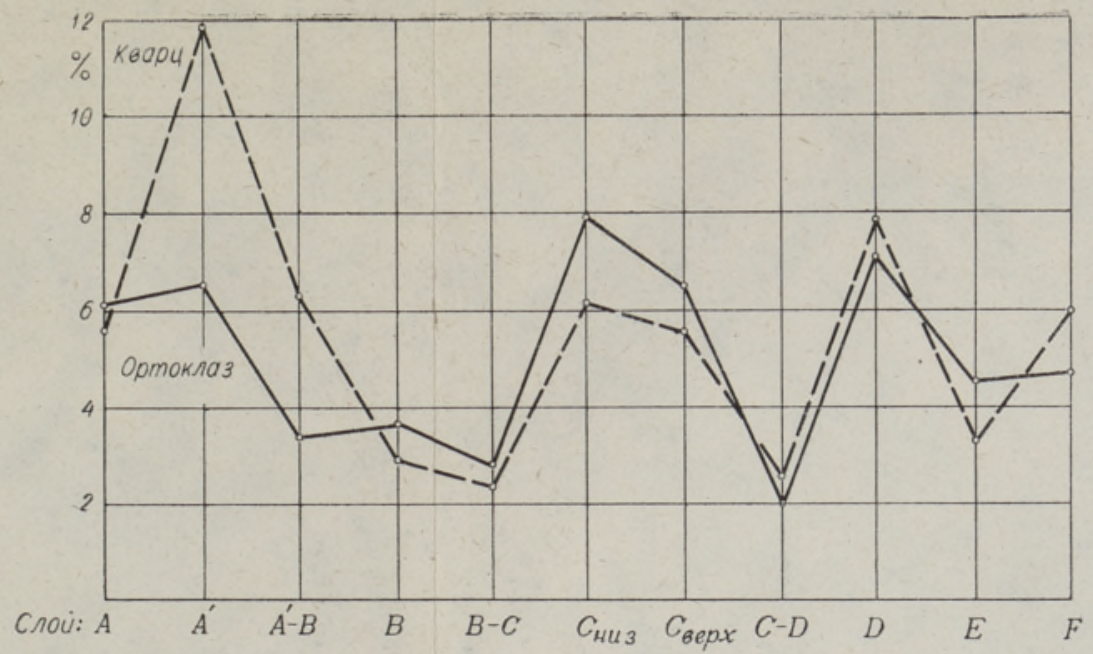

Таблица 3

Содержание зерен кварца различных размеров в сланцевых и известняковых слоях, по данным седиментометрического анализа

\begin{tabular}{|c|c|c|c|c|c|c|c|c|c|c|c|c|}
\hline \multirow[b]{2}{*}{$\begin{array}{c}\text { Размер } \\
\text { зерен, } \mu\end{array}$} & \multirow{2}{*}{$\begin{array}{c}\text { Время } \\
\text { осажде- } \\
\text { дия, мин }\end{array}$} & \multicolumn{11}{|c|}{ Содержание зерен } \\
\hline & & A & $\mathrm{A}^{\prime}$ & $A^{\prime}-B$ & B & $B-C$ & $\underset{\text { (низ) }}{C}$ & $\underset{(\text { верx })}{\text { C }}$ & $C-D$ & D & E & $\mathrm{F}$ \\
\hline$>50$ & 0,75 & 0,25 & 0,14 & 0,42 & 0,45 & 0,41 & 0,70 & 1.50 & 0,35 & 0,83 & 0,88 & 0,73 \\
\hline $50-25$ & 3,00 & 6,10 & 8,32 & 9,77 & 8,64 & 10,16 & 6,98 & 9,90 & 13,63 & 10,43 & 9,91 & 7,70 \\
\hline $25-10$ & 18,75 & 38,20 & 43,88 & 47,83 & 32,76 & 41,24 & 35,32 & 42,40 & 47,97 & 48,87 & 37,69 & 45,60 \\
\hline $10-5$ & 75,00 & 19,00 & 20,40 & 23,60 & 25,10 & 23,70 & 26,50 & 21,60 & 23,10 & 21,20 & 25,6 & 22,00 \\
\hline $5-2,5$ & 300,00 & 23,20 & 12,60 & 8,10 & 18,00 & 10,90 & 15,60 & 15,90 & 8,80 & 12,80 & 14,30 & 10,70 \\
\hline $2,5-1$ & 1860,00 & 6,10 & 9,30 & 6,30 & 10,5 & 9,80 & 8,80 & 7,10 & 4,30 & 4,50 & 9,0 & 10,40 \\
\hline$<1$ & & 7,40 & 5,50 & 4,40 & 4,8 & 4,20 & 6,20 & 3,10 & 2,20 & 2,20 & 3,50 & 3,60 \\
\hline
\end{tabular}

таблица 4

Сравнение результатов гранулометрических определений весовым седиментометрическим методом и методом отмучивания по Сабанину

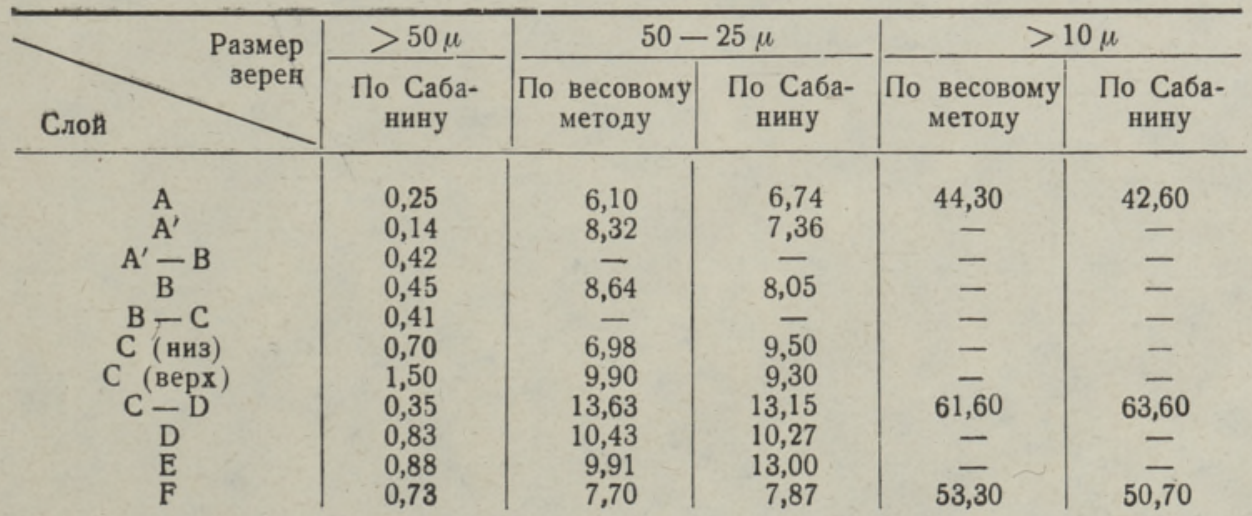

Фиг. 3.

Содержание кварца и ортоклаза в породах, слагающих промышленный пласт горючего сланца (в вес. \% к породе).

Фиг. 4.

Фракционный состав кварца, выделенного из изученных проб.

Фиг. 5.

Относительное содержание зерен кварца одинаковой крупности в слоях (в вес. \% к кварцу). 

ное содержание кварца к алеврито-глинистой составляющей падает по мере увеличения количества последней. Объяснение отмеченных закономерностей следует искать в терригенном происхождении минералов, слагаюших алеврито-глинистую часть породы, и в большей

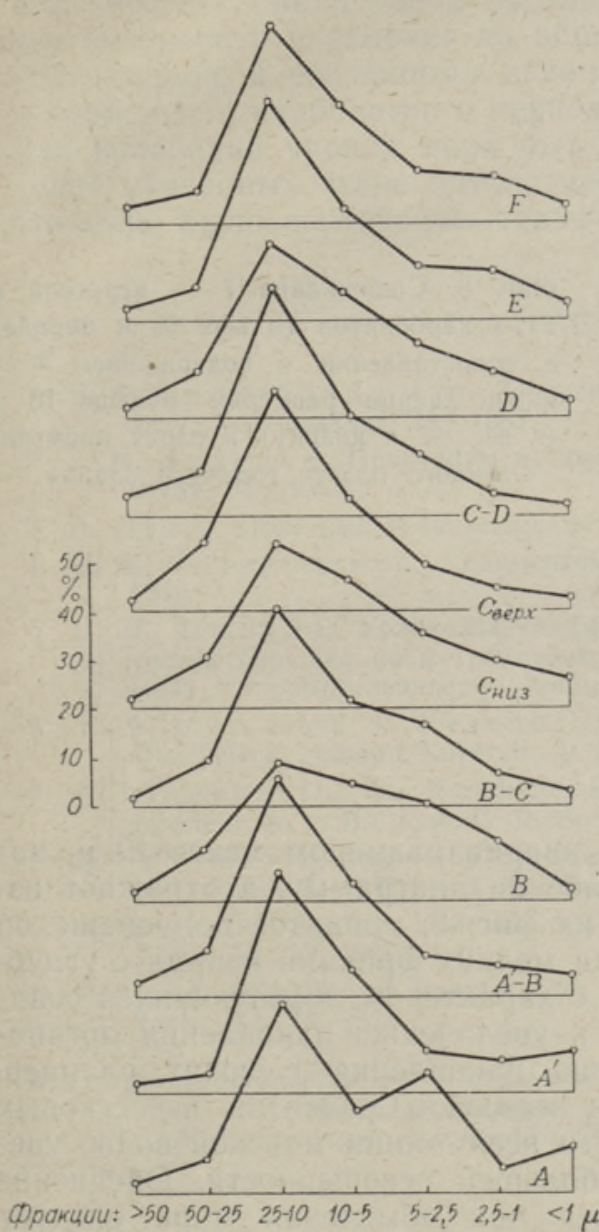

Фиг. 6. Кривые распределения зерен кварца по их крупности в отдельных слоях (в вес. \% к кварцу). устойчивости кварца против истирания и измельчения по сравнению с другими минералами терригенного комплекса, ведущей к накоплению его в более крупнозернистых осадках.

Как и следовало ожидать, исходя из представлений о независимости процессов накопления терригенного и органического компонента сланцевых пород, каких-либо четко выраженных закономерностей в количественном соотношении керогена и кварца не наблюдается ни в известняках, ни в горючих сланцах. По этой же причине не удается установить и зависимость между содержанием карбонатной составляющей и количеством кварца.

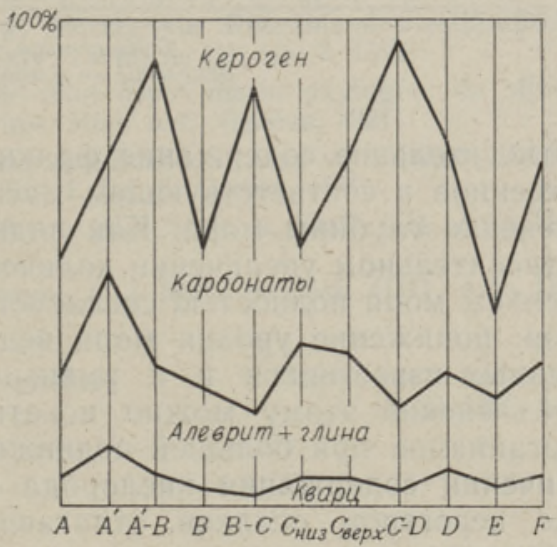

Фиг. 7. Компонентный состав пород промышленного пласта сланца (в вес. \% к породе).

Однако при сопоставлении содержания керогена или карбонатовне с общим содержанием кварца в пробе, а с относительным содержанием зерен кварца различных размеров, выраженном в процентах к общему содержанию кварца в пробе, картина приобретает совершенно иной характер (фиг. 8).

Прежде чем приступить к рассмотрению намечающихся закономерностей, необходимо пояснить способ построения кривой, обозначенной нами на фиг. 8 «глубина моря». При сравнении гранулометрического состава терригенной составляющей отдельных слоев, располагающихся по вертикали на одном и том же участке морского дна, увеличение содержания тонких частиц свидетельствует прежде всего об углублении дна моря или об увеличении расстояния до береговой линии. 
Таким образом, по увеличению или уменьшению относительного количества тонких фракций терригенного кварца в располагающихся друг над другом слоях можно судить об углублении или обмелении моря.

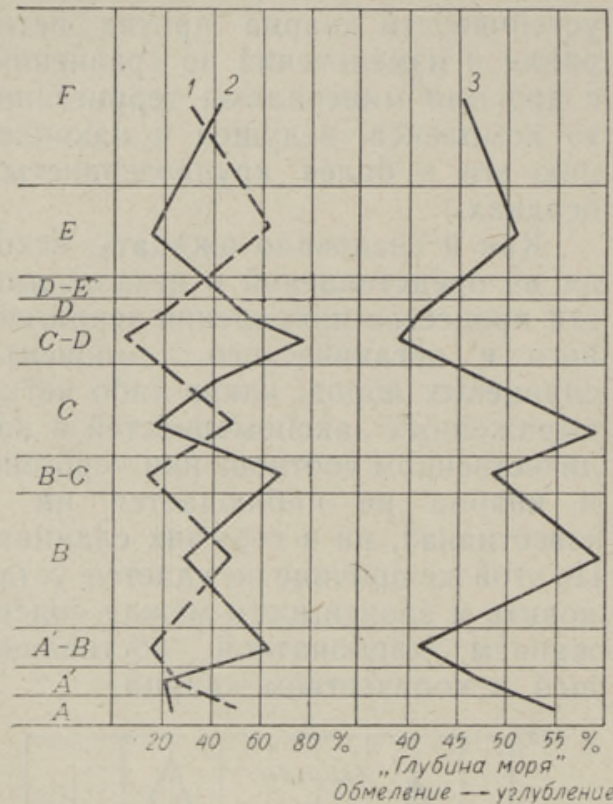

Фиг. 8. Содержание 1 - керогена и 2 - карбонатов (в вес. \% к породе) в сопоставлении с содержанием 3 зерен кварца размером меньше $10 \mu$ (в вес. \% к кварцу) в слоях промышленного пласта горючего сланца.

Относительное содержание фракций кварца размером менее $10 \mu$, нанесенное в соответствующем масштабе на диаграмму, и отражает изменение глубины моря. Как видно из фиг. 8, принятое допущение об относительном увеличении количества мелких фракций кварца с углублением моря полностью согласуется с характером образующихся осадков: понижение уровня моря ведет к увеличению накопления органогенных известняков и к уменьшению накопления горючих сланцев. Объяснение этому можно искать в массовом развитии известковых организмов при большей подвижности всей толщи морской воды, увеличении содержания кислорода и большей освещенности. Обеднение же керогеном осадков, отлагавшихся при обмелении моря, следует объяснять различно, в зависимости от природы его исходного (материнского) вещества: фитопланктон или донные водоросли.

По-видимому, к этому вопросу следует подходить с двух сторон: развитие или угнетение морской флоры, связанное с изменением глубины моря, и изменение условий накопления и консервации падающего на дно моря органического вещества. Оставляя без рассмотрения первую часть вопроса (за отсутствием данных об исходном материнском веществе керогена сланцев), мы хотели бы высказать некоторые соображения о тех факторах, в результате действия которых могло значительно уменьшаться количество накапливаемого органического вещества при уменьшении глубины моря, независимо от планктонного или придонного характера растительности. При обмелении моря следует в первую очередь иметь в виду лучшую аэрацию воды, способствующую быстрому окислению опускающихся на дно моря органических веществ; во-вторых, периодическое взмучивание илистых масс волнением, достигавшим морского дна, что нарушало восстановительный характер среды в придонных отложениях, и в-третьих, усиленное 
поедание растительной массы и переработку ила животными организмами, о большом количестве которых свидетельствует массовое накопление известковых остатков.

Таким образом, изложенные данные позволяют прийти к заключению, что послойная смена органогенных известняков и горючих сланшев по разрезу указывает на периодические изменения глубины моря, гриводившие к усиленному накоплению органической массы в стадии углубления и карбонатов в период обмеления моря. По-видимому, размах колебаний уровня моря был невелик и мог заметно сказаться на смене указанных выше литологических разностей пород лишь потому, что море было неглубоким платформенным бассейном.

\title{
Л ИТ Р Р А У Р А
}

1. В. Ф. Ги ллеб ранд и др., Практическое руководство по неорганическому анализу, Госхимиздат, М., 1957.

2. Г. Н. Ду деров, Практикум по технологии керамики и огнеупоров, Промстройиздат, М., 1953.

3. А. Лух а, Полезные ископаемые Эстонской ССР, Тарту, 1948.

4. Н. А. Фигуровски й, Седиментометрический анализ, Изд. АН СССР, М.-Л., 1948.

5. Н. Н. Цюрупа, Уравнение седиментации и получение кривых распределения частиц порошка по их размерам, Труды Совещания по применению вибропомола в промышленности стройматериалов, Промстройиздат, М., 1957.

6. M. Wittlich und $\mathrm{S}$. Weschnjakow, Beitrag zur Kenntnis des estländischen Olschiefers, genannt Kukersit, Acta Univ. Tartu, A, III, Nr. 7, 1922.

7. H. Lindenbein, La Kuckérsite. Etude d'un dépot marin phytogine du silurien inferieur de la Baltique, C. R. Soc. Phys. Hist. nat., Genève, 1921.

8. A, S ch a m a ri n, Chemische Untersuchung des Brandschiefers von Kukers, Arch. f. Naturkunde Liv-, Ehst- u. Kurlands, Ser. 1, Bd. 5, Dorpat, 1870.

9. A. Op ik, Beiträge zur Kenntnis der Kukruse $\left(\mathrm{C}_{2}\right)$ Stufe in Eesti (II), Acta Univ. Tartu, Nr. 10, 1927.

10. A. Op ik, Beiträge zur Kenntnis der Kukruse $\left(\mathrm{C}_{2}\right)$ Stufe in Eesti (III), Acta Univ. Tartu, Nr. 12, 1928.

Институт строительства и строительных материалов и Ннститут геологии

Поступила в редакцию Академии наук Эстонской ССР

13. II 1960

\section{SETTEANALUUS SETETE TEKKETINGIMUSTE SELGITAJANA}

\author{
N. Dilaktorski, \\ geoloogia-mineraloogia doktor \\ S. Baukov, \\ qeoloogia-mineraloogia kandidaat
}

M. Dilaktorskaja

Resümee

Uurimisele võeti «Eesti Põlevkivi» kaevandusest nr. 10 tootlike kihtide vertikaalläbilōikest (joon. 1) saadud proovid. See materjal kujutas enesest põlevkivikihte A-st kunı F-ini (incl.) ja lubjakivivahekihte $\mathrm{A}-\mathrm{B}, \mathrm{B}-\mathrm{C}$ ja $\mathrm{C}-\mathrm{D}$.

Etüüleetriga niisutamise teel peenendatud proovide järkjärgulisel töötlemisel hapetega (sool-, väävel-, lämmastik- ja fluorboorhappega) eraldati kvarts, mis sisalda s väga vähe lisandeid (rutiili, turmaliini). 
Eri kihtidest saadud kvartsiterade (joon. 4, 5) granulomeetrilise koosseisu määramine setteanalüüsi abil (vesisuspensioonist kaalukausile settinud terakeste kaalumine) võimaldas koostada kvartsiterade suuruse jaotuskõverad (joon. 6) uuritud proovide kohta.

Eri kihtides leiduvate kerogeeni, karbonaatide ja eri diameetriga kvartsiterade suhtelise sisalduse võrdlus (joon. 7,8 ) lubas järeldada, et orgaanilise massi (kerogeeni) kuhjumine toimus mere transgressiooni perioodidel, kuna regressiivsed perioodid tõid kaasa lubjakivide settimise.

Eesti NSV Teaduste Akadeemia

Ehituse ja Ehitusmaterjalide Instituut ja Geoloogia Instituut
Saabus toimetusse

13. II 1960

\section{ANWENDUNG DER SEDIMENTOMETRISCHEN ANALYSE ZUR FESTSTELLUNG DER SEDIMENTATIONSBEDINGUNGEN}

\section{N. Dilaktorski, S. Baukow und M. Dilaktorskaja}

\section{Zusammenjassung}

Es wurden Brennschieferproben nach dem Querschnitt der Schichten (Abb, 1) untersucht; die Proben stammten aus dem Bergwerk Nr. 10 des Trusts «Estonslanetz».

Das untersuchte Material umfasste die Brennschieferschichten von A bis F inclusive und die Kalkstein-Zwischenschichten $\mathrm{A}-\mathrm{B}, \mathrm{B}-\mathrm{C}$ und $\mathrm{C}-\mathrm{D}$.

Durch Schwefeläther desintegrierte Proben wurden sukzessiv mit Säuren behandeit (Salzsäure, Schwefelsäure, Salpetersäure und Fluoroborsäure) und so Quarz ausgeschieden, der bloss verschwindende Quantitäten von Beimengungen (Rutil, Turmalin) enthielt.

Die Bestimmung der granulometrischen Zusammensetzung der Quarzkörner aus den verschiedenen Schichten (Abb. 4, 5), durch eine sedimentometrische Methode ausgeführt - , es wurden die aus einer Wassersuspension auf die Waagschale abgesetzten Körner gewogen -, erlaubte, die Kurven der Verteilung der Quarzkörner (Abb. 6) nach ihren Ausmassen für jede der untersuchten Proben zu bestimmen.

Die Gegenüberstellung des relativen Gehalts an Kerogen, an Karbonaten und an Quarzkörnern verschiedenen Durchmessers (Abb. 7, 8) in den einzelnen Schichten liess schliessen, dass die Anhäufung der organischen Masse (des Kerogens) bei Zunahme der Meerestiefe stattfand, während die Ablagerung der Kalke der abnehmenden Meerestiefe entsprach.

Institut für Bauwesen und Baumaterialien und Institut für Geologie 